Article

\title{
The 'Invisible' Subsoil: An Exploratory View of Societal Acceptance of Subsoil Management in Germany
}

\author{
Ana Frelih-Larsen *, Mandy Hinzmann and Sophie Ittner \\ Ecologic Institute, Pfalzburger Str. 43-44, 10717 Berlin, Germany; mandy.hinzmann@ecologic.eu (M.H.); \\ sophie.ittner@ecologic.eu (S.I.) \\ * Correspondence: ana.frelih-larsen@ecologic.eu
}

Received: 8 June 2018; Accepted: 14 August 2018; Published: 24 August 2018

\begin{abstract}
Subsoil, commonly defined as horizons below the working depth of $30 \mathrm{~cm}$, has traditionally received little explicit attention in policy discussions on soils. Recently, however, there has been growing recognition among scientists of the issues of subsoil (re-)compaction and of the role of subsoil as a resource that can offer valuable nutrients and water for plants. Subsoil management could provide an option to sustainably maintain yields in the context of climate change and resource scarcity, and it is a central question in addressing subsoil compaction. Yet how socially acceptable are different methods for subsoil management? Drawing on in-depth interviews with farmers and stakeholders in Germany, we show that biophysical conditions, the timing of operations, economic considerations, and awareness of subsoil functions are key factors in the acceptance of management methods. Views towards methods involving mechanical intervention are more diverse and in some cases more critical because the benefits are not always certain, the costs can outweigh the benefits, and/or because they entail risks for soil structure and functions. Alfalfa cultivation is seen to be beneficial for yields without risks for soil structure and functions; however, economic barriers limit its uptake. Awareness of multiple subsoil functions is associated with more critical views of mechanical interventions.
\end{abstract}

Keywords: subsoil; compaction; agricultural yields; soil functions; societal acceptance; farmer motivations; subsoil loosening; alfalfa; sustainable soil management; resource scarcity; Germany

\section{Introduction}

Soils tend to receive less public attention than other environmental resources. Whereas water, air, or biodiversity tend to be more visible publicly, soils have historically not been a focus for environmental campaigning or large societal debates. At the policy level, in the European Union, soils are the only resource without a binding overarching legislation at the EU level [1,2]. In recent years, some attention on soils has been refocused, for example, with the UN declaring 2015 as the Year of Soils, as well as initiatives such as ' 4 per mil' within the international climate change negotiations. Nonetheless, society tends to have less direct engagement with soils compared to other resources.

The subsoil, commonly defined as the horizons below the working depth of $30 \mathrm{~cm}$, is also physically invisible to societal stakeholders, including farmers. In practice, farmers' interaction with the soil tends to focus on the topsoil, which is the medium with which they interact (e.g., through tilling or ploughing in conventional farming systems). The topsoil is also where the effects of management decisions are most clearly seen. Subsoil tends to become an issue for farmers and farm advisers when it becomes compacted and when waterlogged subsoil layers decrease yields. Similarly, subsoil has been explicitly addressed in the scientific literature, often in relation to problems with subsoil compaction, 
a persistent and damaging process that severely restricts the ability of soils to perform soil functions and deliver ecosystem services (for example, [3]).

In terms of policy discussions, the main issue has also been subsoil compaction. However, because subsoil compaction does not always have immediate visible effects, such as is the case with soil erosion or topsoil compaction, and because of difficulties with designing a policy response to it, it has also not been a widely discussed soil protection issue. Compaction in general has been described as a "hidden problem" [4]. Yet, it has also been argued that it should be treated as a priority problem, as "with the increasing frequency and gravity of weather extremes under climate change (drought spells; intense precipitation; flooding), subsoil conditions in terms of hydraulic properties and ability to support deep rooting will increase in importance" [5] (p. 86).

From a more positive perspective, subsoil has the possibility to attract more attention in policy discussions within the agenda on climate change adaptation and with the increasing awareness of resource scarcity issues (see for example [6,7]). Subsoil can offer valuable nutrients and water for plant growth. Recent research has shown that, although nutrient availability to crops can vary, subsoil can contain a large share of the total Nitrogen and Phosphorus contained in the soil and retain water under drought conditions [8-13]. Moreover, subsoil is also important for other soil functions and ecosystem services, including flood protection, water filtration, or carbon storage [14,15]. Integrating subsoil in management decisions may be an opportunity to tap an additional resource of nutrients and water. In the context of climate change, subsoil management can also potentially be seen as an option to sustainably maintain or increase yields [10,12]. While its role as a source of nutrients and water is hinted at in policy, and potentially fits well with the discourse of the Bioeconomy and Circular Economy Agenda in the EU, it is not yet an explicitly articulated aspect of any policy discussions.

In this context, researchers have begun to look more systematically at subsoil functions/the role of subsoil for soil functions and to develop and investigate new strategies of mechanically or biologically intervening in subsoils that aim to tap the subsoil as a resource [10-13,16-18]. Yet how relevant, feasible, and acceptable are different methods for subsoil management as a strategy that can contribute to the sustainable management of soils and to securing long-term agricultural yields? How do farmers and other stakeholders view subsoils, and are farmers interested in adopting different subsoil management measures? Are these measures also acceptable from a broader societal point of view? These questions have not yet been addressed in social science or policy discussions. If one or more subsoil management measures are framed as having the potential to deliver benefits for agricultural yields and to be implemented (more) broadly in agricultural management, it is important to understand how societal stakeholders see these measures and which factors either increase their appeal or present a barrier to their uptake and social acceptance.

This article presents an exploratory look at stakeholders' perceptions of subsoil and societal acceptance of subsoil management methods in Germany. The article is based on research in an interdisciplinary project on subsoil management, titled "Soil ${ }^{3}$-Sustainable Subsoil Management" (The Soil ${ }^{3}$ project explores strategies to optimize a plant's uptake of nutrients and water from the subsoil in order to stabilize or increase crop yields. See https://www.soil3.de). The method combines a literature review with in-depth interviews. The exploratory examination is not comprehensive. Rather, we identify key issues and develop a basis for a more extensive social acceptance analysis that will take place in the second phase of the Soil ${ }^{3}$ project and will combine a broad survey with targeted focus groups, as well as ongoing stakeholder engagement with the development and testing of subsoil management methods. The options for subsoil management broadly fall into mechanical and biological management methods [12]. In this study, we explored views towards four methods: (1) deep ploughing, (2) mechanical subsoiling, (3) a new method of mechanical subsoiling with an injection of organic matter, and (4) the cultivation of deep-rooting alfalfa crop.

The article is structured as follows. We first outline the method and the overall conceptual approach for the study. Second, we show how stakeholders perceive the subsoil and what kind of awareness of the subsoil they have. Third, we show how stakeholders view the different management 
methods, and what positive and negative aspects they emphasize in relation to each method. Finally, in the discussion, we relate the results of the study to broader discussions on sustainable (sub)soil management and the questions raised for further research.

\section{Materials and Methods}

The research for this article included a literature review on farmers' decision-making around sustainable soil management, which showed that the topic of subsoil management has mostly been absent as an explicit topic in social science research so far. We could not identify any published research that looks at how farmers use or do not use subsoil management measures. However, the review provided an overall framework for approaching the societal acceptance analysis, which we present in Figure 1. We also examined how the soil science literature approaches subsoil management. In addition, in-depth interviews in Germany were conducted with nine soil management stakeholders and nine farmers who practice either arable or mixed farming systems. While farmers are of course also societal stakeholders, in this article, we make the distinction between farmers and other stakeholders to simplify the terminology and presentation of results. The overview of interviewed stakeholders and farmers is given in Table 1.

Table 1. Overview of interviewed soil stakeholders and farmers.

\begin{tabular}{cccc}
\hline No. & Occupation & Organisation & Federal State \\
\hline 1 & Farm advisor & Farmers' association & Brandenburg \\
2 & Farm advisor & Farmers' association & Mecklenburg-Western Pomerania \\
3 & Farm advisor & Chamber of agriculture & Nhine-Westphalia \\
4 & Farm advisor & Independent farming consultancy for farmers and policy-makers & National level \\
5 & Public official & Environmental ministry & Lower Saxony \\
6 & Public official & Agency for the environment and energy, federal soil association & Hamburg \\
7 & NGO representative & Environmental NGO & National level \\
8 & Scientist & Soil protection advisory board & National level \\
9 & Scientist & University & Lower Saxony \\
10 & Farmer & Brganic farm, mixed farm (cattle): 180 ha & Brandenburg \\
11 & Farmer & Mixed farm (cattle): 700 ha, 250 dairy cows & Mecklenburg-Western Pomerania \\
12 & Farmer & Mixed farm (pigs): 500 ha & Mecklenburg-Western Pomerania \\
13 & Farmer & Mixed farm: 1300 ha, 2000 pigs & Mecklenburg-Western Pomerania \\
14 & Farmer & Arable farm: 800 ha & Mecklenburg-Western Pomerania \\
15 & Farmer & Mixed farm: 100 ha, 1150 pigs & Bavaria \\
16 & Farmer, part-time farm advisor & Mixed farm: 50 ha, 500 pigs & Bavaria \\
17 & Farmer, part-time farm advisor & Arable farm: 190 ha & Bavaria \\
18 & Farmer & Arable farm: 2700 ha & Brandenburg \\
\hline
\end{tabular}

The stakeholders included representatives of a range of institutions associated with soil management and soil protection, including practitioners working in farmers' organisations, non-governmental organisations, and public authorities. Four practitioners worked at a national level and four in federal states (Mecklenburg-Western Pomerania, Brandenburg, Lower Saxony, and North Rhine-Westphalia). Farm interviews were conducted in Northern and Southern Germany (Mecklenburg-Western Pomerania, Brandenburg, and Bavaria). We identified farmers with the assistance of regional farm advisors. The aim was to capture a range of farms practicing arable or mixed farming. The interview guide focused on three main themes: (1) views on good agricultural practice and soil management, (2) views on soil functions and the role of subsoil, and (3) views on acceptable solutions to addressing soil threats associated with agriculture. Interviews were recorded and transcribed, and the transcripts were then analysed.

In this exploratory stage, we intentionally approached professional and larger, likely more intensive, farms who might have already experienced problems of subsoil compaction and who might be more open to new technologies. While the sample size is small, the diversity of interviewees and open-ended/in-depth nature of interviews allows us to identify a range of perspectives and explore diverse variables and interactions among them. This qualitative and exploratory examination provides the basis for a broader survey and focus groups that we will conduct in the second phase of the project. 


\subsection{Farmers as Actors in Context}

Conceptually, the starting point for our analysis is the framework of farmers as actors in context. This means that farmers are seen as active agents who operate and negotiate their decisions with regards to farming practices within a context of various constraints, and as participants in complex spatially and temporally specific horizontal and vertical networks and processes [19]). Farmers' decision-making is therefore a result of a complex interplay of processes and influences from the broader farm environment, the biophysical and economic conditions on the farm, which are mediated by farmers' agency, their views, perceptions, and norms (compare Figure 1). The relative role of different variables and their interactions differ across space and time.

Mills et al. (2016) differentiate between the 'ability to adopt' and 'willingness to adopt' certain farming techniques [20]. Farmers' ability to engage with a particular method or to adopt an environmental measure depends to a large degree on farm characteristics such as farm size, tenure, and income.

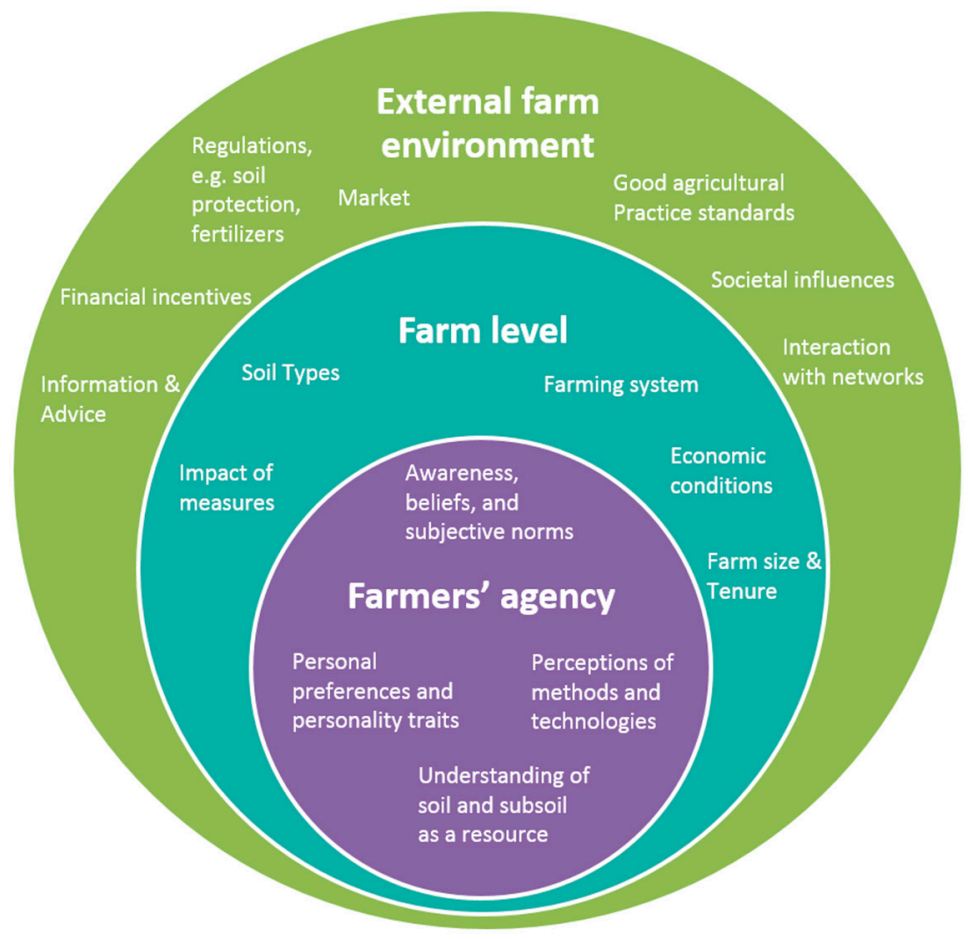

Figure 1. Farmers as actors in context (adjusted from [20]).

The willingness to apply a technique, on the other hand, is more strongly related to intrinsic factors such as personal norms and beliefs. Farmers' understandings, problem framings, and mental models regarding soil and agriculture have an influence on how soil is managed and which management options are accepted [21-23]. For example, Prager et al. (2016) observe: "How a person perceives soil degradation will influence how they interpret this phenomenon, what attitude they adopt towards it, and how they will ultimately decide to act" [21] (p. 36). Awareness and knowledge of soil risks can thus be a motivating factor for adopting soil protection measures [24]. In addition to these influences, there is also a need to consider farmers' technical knowledge of soil management: if farmers lack confidence or competence in certain new management practices, this can present further barriers to uptake [25]. Exploring the acceptance of subsoil management measures therefore requires attention to a broad range of factors. 


\subsection{Subsoil Management Methods}

We consider four different subsoil management techniques that aim to enable crops to better access subsoil resources (compare Table 2).

Table 2. Subsoil management methods.

\begin{tabular}{|c|c|c|c|}
\hline Deep Ploughing & Mechanical Subsoiling & $\begin{array}{l}\text { Injection of Organic Matter Furrow-Wise } \\
\text { into the Subsoil }\end{array}$ & Alfalfa \\
\hline $\begin{array}{l}\text { The soil is ploughed to } \\
\text { the depth of } 50 \mathrm{~cm} \\
\text { and turned }\end{array}$ & $\begin{array}{l}\text { Mechanical subsoil } \\
\text { loosening, also referred to as } \\
\text { "subsoiling", uses deep } \\
\text { blades to loosen the soil and } \\
\text { break up compacted layers } \\
\text { without turning soil over }\end{array}$ & $\begin{array}{l}\text { New technique combines mechanical } \\
\text { subsoil loosening with the injection of } \\
\text { organic materials in the subsoil. In furrows } \\
\text { of about } 30 \mathrm{~cm} \text { width (and intervals of } \\
\text { about } 1 \mathrm{~m} \text { between furrows), organic } \\
\text { material is mixed into the subsoil by means } \\
\text { of specially designed machinery }\end{array}$ & $\begin{array}{l}\text { Alfalfa cultivation is a } \\
\text { biological method of subsoil } \\
\text { loosening by means of } \\
\text { deep-rooting plants to create } \\
\text { vertical root channels } \\
\text { (biopores) for } \\
\text { subsequent crops }\end{array}$ \\
\hline
\end{tabular}

Deep ploughing involves digging into and turning the soil at a depth of about $50 \mathrm{~cm}$ or deeper, leading to an inversion of the soil profile (i.e., former subsoil is brought to the surface while topsoil is buried). It aims to break up root-restricting soil layers and to optimise crop growing conditions [18]. Deep ploughing used to be widely practiced in Germany and the Netherlands in the 1960s for the reclamation of peatlands for agricultural use, as well as to improve cropping conditions on Podsols and Luvisols [12]. The technique requires great physical effort, i.e., heavy machinery and a high input of energy. Among the four subsoil management techniques included in our analysis, deep ploughing is the most intense operation on the soil.

Mechanical subsoil loosening, which is often referred to as "subsoiling" or "deep ripping", aims to loosen the soil and is primarily applied to counteract subsoil compaction. Loosening the subsoil is supposed to increase crop yields by enabling deeper and wider root growth, improving water infiltration and transport, as well as facilitating nutrient uptake [26]. Various tillage tools exist for the purpose of subsoil loosening; often, grubber-like appliances with one or several grongs are used and the depth of application can vary between 35 and $50 \mathrm{~cm}$ (compare for example [26,27]). In contrast to deep ploughing, mechanical subsoil loosening does not turn the soil.

A new technique to meliorate the subsoil that is currently tested in field experiments [10] combines mechanical subsoil loosening with the injection of organic materials (green cuttings, organic compost). The aim of the technique is to modify the soil structure to enable the deeper rooting of crops, trigger microbial activity, and eventually enhance yields. To farmers and stakeholders we interviewed, we explained the procedure as follows. The technique is applied furrow-wise with intervals of about $1 \mathrm{~m}$ between furrows, with the furrow being approximately $30 \mathrm{~cm}$ wide. First, the topsoil layer (upper $30 \mathrm{~cm}$ ) is lifted and put aside. Second, organic materials are inserted into the furrow. Third, the organic materials are mixed into the subsoil down to a $60 \mathrm{~cm}$ depth. Finally, the topsoil is laid back on top. The technique does not involve turning the soil profile and the topsoil remains untreated. Ideally, plant roots will grow into the furrow from the top as well as from the sides. The first results of the field experiment testing the technique on a loess soil showed that one year after implementation, yields of spring barley increased by up to $20 \%$. Positive yield effects could be observed up to $50 \mathrm{~cm}$ sideward of the treated furrow [10]. The technique can be site-specifically adapted, e.g., regarding intervals between the furrows, depth of application, and choice of input materials.

A biological approach-also referred to as "biodrilling" or "bioporing" — to loosen and meliorate the subsoil and enhance water infiltration is the cultivation of deep-rooting primer crops such as alfalfa. These plants create vertical root channels (biopores) and thus facilitate deep rooting and access to subsoil resources for the subsequent crop [13]. Alfalfa is very suitable as it develops a strong taproot reaching deep soil layers, as well as multiple branches that create a broad root network [3,9,17]. It is argued that alfalfa and other deep-rooting plants can alleviate subsoil compaction [3,28,29]. In fact, alfalfa cultivation used to be a standard technique for the reclamation of agricultural soils following 
degradation through brown coal mining processes. For developing taproots, alfalfa must remain on the field for at least two years.

\section{Results: Subsoil Awareness and Acceptance of Management Measures}

\subsection{Subsoil Awareness}

We anticipated that farmers have a relatively limited awareness of subsoil since they mostly deal with the topsoil in their everyday operations. Many farmers in the sample shared this view by stating that a typical farmer will think little of soil management and even less of subsoil. Several said that an active consideration of subsoil only occurs in exceptional circumstances, whereas normally, farmers do not come into contact (directly or indirectly) with the subsoil.

"Soil is often the last thing a farmer thinks of when problems occur-first he checks fertilisation regime, plant protection, choice of crops and so on-soil or subsoil is the last thing he thinks of" (No. 17).

Having said this, farmers included in the sample were well informed and engaged with soil management. They were all aware of good soil management practices and many have been applying these practices, in particular crop rotation and making traffic and tillage decisions based on weather and site conditions. In relation to soil functions broadly, most farmers emphasized the role of soils as a storage for nutrients and water (seven of nine farmers), with carbon storage also mentioned by two farmers. When asked about the role of the subsoil more specifically, farmers spoke about it primarily in terms of a reservoir. In particular, subsoil becomes more relevant in conditions where the topsoil is less productive and has a limited water- or nutrient-holding capacity. Six of the nine farmers mentioned the importance of subsoil as a reservoir for nutrients and water, especially under extreme weather conditions. However, only one farmer/farm advisor emphasized the subsoil's function as a filter for groundwater, implying a more explicit awareness of the role of soils for maintaining water quality. Two farmers did not refer to subsoil specifically and one stated that, on his land, the topsoil transitions very quickly into bedrock so that a subsoil layer is hardly present.

Among the societal stakeholders, three stakeholders from agricultural organisations echoed this focus on the subsoil as a reservoir, emphasizing its crucial role for water balance. In contrast, five other stakeholders with a background in environment protection had a broader view of subsoil, equally emphasizing all soil functions as defined in the German Soil Protection Law, i.e., in addition to the production function (as a reservoir of nutrients and water), the natural and the archive functions of soils were attributed equal importance. In particular, they emphasized the filtration, buffering, carbon storage, and habitat functions. One pointed to the fact that the climate (carbon storage) function is missing from the German Soil Protection Law. One agricultural and one environmental stakeholder also stated that a distinction was not possible and that topsoil and subsoil were equally important. Despite the small sample size, the more 'production' focused view of farmers and agricultural stakeholders is in clear contrast with a more 'multifunctional' view of subsoil by the environmental stakeholders.

If we look at the idea of subsoil as a reservoir, the significance of subsoil in Germany increases in regions with sandy soils, which are also more prone to drought, such as Brandenburg and Mecklenburg-Western Pomerania. To illustrate the limited water-holding capacity of sandy soils, one farmer explained that his soils have the potential to save perhaps up to $50 \mathrm{~mm}$ of water in the top $25-30 \mathrm{~cm}$ of soil (per $\mathrm{m}^{2}$ ), which is sufficient to keep plants alive for a week or ten days in warm, sunny, conditions. Beyond this short period, the plants have to depend on the subsoil. Recognizing this function goes along with a higher appreciation of the subsoil, illustrated by the statement of an agricultural stakeholder: "Every centimeter of additional soil volume is a centimeter of additional habitat for plant and soil life, which later on is mirrored in the crop yield and quality of products" (No. 1). This function of subsoil as a reservoir is of importance as one factor that can help to reduce yield fluctuations, in particular on sandy soils. Six of nine farmers stated that increasing the yield 
stability, or achieving the optimum yield, and reducing annual fluctuations due to changing weather conditions, were important objectives of their farm management. The appreciation of the subsoil as a reservoir is not necessarily limited to areas with sandy soils, since farmers in Bavaria also emphasized this. The two out of three Bavarian farmers that mentioned it, however, were also part-time advisors for soil management so it may still be possible that in Bavaria, where soils tend to be more productive, the overall awareness of subsoil is lower.

In addition to poor topsoil quality, compaction problems are another motivating factor that farmers gave as reason to think about subsoil. Six of nine farmers mentioned the issue of compaction as an important soil threat, with several speaking of the role of heavy machinery and inappropriate timing of operations in worsening the problem, and several also had either a positive or negative experience with subsoil mechanical loosening. While compaction affects sandy soils more, farmers with other soil types also reported issues of compaction, especially along driving lanes. Another aspect mentioned by a couple of farmers in relation to subsoil was the issue of drainage, which, in many parts of Germany, allows the cultivation of rich organic soils.

\subsection{Acceptance of Subsoil Management Methods}

\subsubsection{Deep Ploughing}

The first method that farmers and stakeholders were consulted on was included in the study as the most invasive form of mechanical intervention in the subsoil. Farmers' and stakeholders' views on deep ploughing are summarised in Table 3. Views are quite similar, with the general opinion being that the method is not an effective one to deal with subsoil compaction. While deep ploughing was once quite popular in Germany, and often applied on organic rich soils (peatland) (No. 6, No. 13), it is no longer practiced widely in Germany.

Table 3. Stakeholders' views on deep ploughing.

\begin{tabular}{cc}
\hline Positive & Negative \\
\hline $\begin{array}{c}\text { On a case-by-case basis acceptable, if there is } \\
\text { no other solution } \\
(5,9,7)^{1}\end{array}$ & $\begin{array}{c}\text { Strong opposition to mixing topsoil and subsoil and } \\
\text { bringing soil to the top } \\
(1,2,3,4,5,6,7,8,18)\end{array}$ \\
\hline & Detrimental effects to soil structure, soil functions \\
and soil life \\
$(2,4,5,6,7,8,16,17)$
\end{tabular}

Numbers in parentheses indicate the No. of stakeholders and farmers who mentioned the respective aspect.

A few farmers and stakeholders referred to it as an outdated technique and one stakeholder characterized it as a 'purely desperate measure'. Nearly half of the interviewees mentioned the high energy and time effort as a negative aspect. Several stakeholders explicitly stated that it is not acceptable under any circumstances. Half of the interviewees, primarily the stakeholders, voiced strong opposition against the mixing of topsoil and subsoil. Eight emphasized that this leads to the destruction of the soil structure and thereby seriously affects all soil functions. One farmer mentioned the following negative experience:

"I know the method from the farm where I worked on in Denmark. We used a very large plough to till peatland. This was done only for a few years. We don't do it anymore. We stopped doing it because these organic soils ... they collapse even faster, the more oxygen you add to it, the faster they collapse" (No. 13). 
One stakeholder said the mixing of layers as deep as $90 \mathrm{~cm}$ affects the soil organic matter (SOM) content in the topsoil, a negative impact especially for topsoil with an already low SOM content (No. 2). Another stakeholder also referred to the method as bringing up 'dead soil', by which they meant that a layer of soil with a very low biodiversity is put on top, and some organisms are pushed down to the depth where there is not enough light and oxygen for them to survive (No. 4). This could lead to the destruction of biodiversity in topsoil and subsoil, potentially being counterproductive in both ecological and economic terms. Only three stakeholders mentioned that they found the method acceptable only as a one-off measure if it is associated with a shift in a system change:

"I can understand that if you have to do it, you do it. But if you don't change your whole management, then you'll end up at the same point in a few years that you'd have to repeat it again, and that's no solution" (No. 7).

One of these three stakeholders also emphasized that its acceptability depends on the time horizon; if it is done infrequently, there is still the question of how the topsoil responds to the measure and how long it has to recover, since the immediate negative effect (in this case, the reduction of SOM in the topsoil) would eventually be evened out.

\subsubsection{Mechanical Subsoil Loosening}

Overall, interviewed farmers and stakeholders see mechanical subsoiling rather critically (compare Table 4). They see a high risk of damaging the soil when the technique is not applied carefully. A number of farmers and agricultural stakeholders describe mechanical subsoiling as a standard technique for loosening compacted soil layers underneath driving lanes and headlands. Yet, many emphasise that a field-wide application of the technique needs to be considered with caution and is only acceptable under certain restrictions: i.e., the technique is performed on dry soils, as a one-time measure, and in combination with a suitable crop rotation.

Table 4. Stakeholders' views on mechanical subsoiling.

\begin{tabular}{|c|c|}
\hline Positive & Negative \\
\hline $\begin{array}{l}\text { Suitable for heavily compacted sites, primarily under } \\
\text { driving lanes and headlands } \\
(1,2,3,4,5,7,11,12,13,14,18)\end{array}$ & $\begin{array}{l}\text { Risk of re-compaction, complete loss of soil structure or } \\
\text { shift compaction into deeper layers } \\
\qquad(2,5,7,10,16,17)\end{array}$ \\
\hline $\begin{array}{l}\text { Accepted on dry soils / light and sandy } \\
\qquad(1,2,10,12,13,16,18)\end{array}$ & $\begin{array}{l}\text { High efforts and costs, heavy machineries and high energy } \\
\text { input is needed } \\
(3,6,7,8,10,12,15)\end{array}$ \\
\hline \multirow[t]{2}{*}{$\begin{array}{l}\text { Only in combination with biological activation, catch } \\
\text { cropping or diverse crop rotation } \\
\qquad(2,4,6,7,10,12,18)\end{array}$} & $\begin{array}{l}\text { Not suitable for subsoils with stones and drainage systems } \\
\qquad(14,15)\end{array}$ \\
\hline & $\begin{array}{l}\text { Short-sighted solution, without implementing any changes } \\
\text { in the farming system that aim to prevent new compaction, } \\
\text { lead to the need to repeat the procedure again after a short } \\
\text { period of time } \\
\qquad(1,5,6,7)\end{array}$ \\
\hline
\end{tabular}

Subsoiling requires heavy machinery and a high input of energy to loosen deep soil layers, making it an intense operation that involves high efforts and costs. One rather sceptical farmer therefore described the technique as a "gigantic technological effort" with rather marginal results (No. 10). Nonetheless, it appears acceptable to alleviate compaction on specific sites and five of the nine farmers reported experience with mechanical subsoiling at a depth varying between $35 \mathrm{~cm}$ and $120 \mathrm{~cm}$. Four farmers stated that they currently used mechanical subsoiling on their farms, primarily to loosen driving lanes and headlands, emphasizing that they use the subsoiler on parts affected by compaction but not field-wide. Two farmers applied the technique once on a larger scale: one of them (No. 13) when he took over the farm and found that many fields were heavily compacted due to 
frequent traffic, and the other (No. 11) when he changed his farming system from ploughing to no-till cultivation. Another farmer (No. 16) had a very negative experience with mechanical subsoiling. After applying the technique at a $45 \mathrm{~cm}$ depth, he found that the soil structure was lost, water infiltration decreased, and the soil's carrying capacity collapsed.

The high risk of re-compaction and the increased loss of soil functions are the most critical issues that limit the acceptance of mechanical subsoiling. Many see it as a short-sighted solution, stressing that it should be combined with biological measures, such as deep-rooting catch crops, in order to be effective. The roots reactivate the soil life and stabilise the loosened structure. As an illustration, one farmer described mechanical subsoiling without subsequent catch cropping as a "waste of fuel and effort" (No. 12). A second farmer took on an even more critical perspective, stating that mechanical subsoiling "only removes agronomical mistakes a farmer has made in the past. Although it does not really remove them, but rather shift compaction into deeper layers if not done under dry conditions and if not combined with catch cropping" (No. 10). Mechanical subsoiling damages the soil when applied under wet conditions: "You can make mistakes with mechanical subsoiling, which result in structural damages. It is important to apply the technique under dry conditions. To look at the soil, combine the technique with catch cropping, with deep-rooting catch crops. Most importantly, you need to consider the water conditions in the soil. Otherwise you exponentially increase harmful compaction" (No. 2).

Particularly the environmental stakeholders that have a multifunctional view of soils expressed concern about the frequency of application. A few stakeholders mentioned that farmers exploit this technique as a quick solution to compaction, enabling them to continue with business as usual-e.g., maintaining a wheat-dominated crop rotation-without implementing any changes in the farming system that would prevent new compaction. In this way, the technique fixes the symptom but not the cause of compaction issues and regular application is neither justifiable nor sustainable (No. 6): "Experiences with mechanical subsoiling show that the technique can definitely cause damages when applied under unfavourable conditions" (No. 9). This view resonates with the opinion that "soil should be cultivated in a way that the transition to subsoil remains intact and no mechanical intervention is needed" (No. 1).

Regular application, indeed, appears to be quite common, except in conditions that limit its application because of biophysical factors-i.e., in areas with a high frequency of stones, drainage systems, or very heavy soils. Interviewees report of a widespread opinion in certain regions of Northern Germany that subsoiling on a regular basis is an adequate farming practice for light and sandy soils, which tend to compact easily (No. 2, 12,14), as well as on all soils on farms with root crops (potatoes, onions, sugar beets) that use heavy harvesting machinery. This hints to an apparent lack of awareness of the long-term damage to subsoil. However, even when farmers are aware of the risk of compaction, economic and time pressures often outweigh the concern about the compaction risk. This is illustrated by a farmer in the sample who used a subsoiler to get rid of water on a field he wanted to harvest—although aware that this is harmful for the soil: "It's a catastrophe for the soil what we are doing, but we have to get the beets out and it's too wet" (No. 14). Farmers are pressured to harvest by conditions set out in their contracts to supply specific amounts at certain times. Given that six of nine farmers mentioned the prevention of compaction as part of good soil management, it appears that economic and time concerns outweigh precautionary behaviour.

The technique is in part risky because the damage done to the soil in the subsoil layer is not immediately visible and it is not easy to judge whether the subsoil is wet or dry (No. 16). This aspect of not being able to see the subsoil requires that farmers dig into the soil first and have a look at the subsoil conditions, a practice that farmers do not often do under time pressure. It is also worth noting in this context the sentiment expressed by several farmers in the sample that farmers in general do not pay so much attention to soil conditions compared to the plants and fertilisation. For example, one farmer stated, "who do you see these days doing a spade test?" (No. 17). 


\subsubsection{Injection of Organic Matter Furrow-Wise into the Subsoil}

The views on the innovative technique of injecting organic material furrow-wise into the subsoil were quite diverse. While some of the interviewed farmers and stakeholders were enthusiastic and showed great interest, others were rather cautious and expressed concerns, and a few interviewees found the technique unacceptable (compare Table 5).

Table 5. Stakeholders' views on injecting organic matter furrow-wise into the subsoil (Soil ${ }^{3}$ method).

\begin{tabular}{|c|c|c|}
\hline Positive & Negative & Uncertainties \\
\hline $\begin{array}{c}\text { Enhancing site conditions/soil } \\
\text { structure (in regions with sandy } \\
\text { soils and low SOM) } \\
(2,6,9,10,12,13,16,18)\end{array}$ & $\begin{array}{c}\text { Risk of disturbing soil structure; } \\
\text { difficult to preserve the structure } \\
\text { of the topsoil } \\
\qquad(3,4,5,8,9,11,17)\end{array}$ & $\begin{array}{l}\text { Sustainability of yield increase- }- \text { how long } \\
\text { does the effect last } \\
(2,14,16,17)\end{array}$ \\
\hline $\begin{array}{l}\text { Improve root development, } \\
\text { enhance biological activity in } \\
\text { lower soil layers and the ability to } \\
\text { store water and nutrients and } \\
(1,2,6,9,11,12,13,14,18)\end{array}$ & $\begin{array}{l}\text { Risk of anaerobic decomposition } \\
\text { process (rotting) in subsoil } \\
\text { (especially on heavy soils with low } \\
\text { air circulation-nutrients are not } \\
\text { available for plants) } \\
(3,4,8,9,10,12,15,17)\end{array}$ & $\begin{array}{l}\text { Are the expected benefits worth the high } \\
\text { effort, in particular in comparison to other } \\
\text { management practices } \\
\qquad(1,2,4,5,8,15)\end{array}$ \\
\hline $\begin{array}{l}\text { Stabilising yields (in dry regions } \\
\text { with sandy soils) } \\
(1,2,6,10,11,13,18)\end{array}$ & $\begin{array}{l}\text { High effort and costs, need } \\
\text { powerful machinery to implement } \\
\text { the technique (prevent particularly } \\
\text { small farms to apply the } \\
\text { technique) } \\
(1,2,3,4,6,7,8,10,11,12,13,15 \\
\text { 17) }\end{array}$ & $\begin{array}{l}\text { Doubtful, whether the aims of the Soil } \\
\text { Protection Law, Fertiliser Regulation, and } \\
\text { waste legislation, i.e., to sustain all soil } \\
\text { functions, can be met with this technique } \\
\qquad(2,5,6)\end{array}$ \\
\hline \multirow[t]{2}{*}{$\begin{array}{c}\text { Attractive for sites with high yield } \\
\text { or for crops with very high } \\
\text { added value } \\
(3,10,12,13,16)\end{array}$} & $\begin{array}{l}\text { Dependence on external } \\
\text { consultants } \\
(4,7)\end{array}$ & $\begin{array}{l}\text { Doubts that soil life will be attracted to go } \\
\text { deeper into the soil } \\
\qquad(7,4)\end{array}$ \\
\hline & $\begin{array}{l}\text { Penetrating to such depths } \\
\text { mechanically is not advisable (17) }\end{array}$ & $\begin{array}{l}\text { Buffer function of the soil could be affected; } \\
\text { risk of contaminants in input } \\
\text { material—leads to groundwater pollution, } \\
\text { quality of input material needs to be } \\
\text { guaranteed } \\
(2,5,6,12,13,14)\end{array}$ \\
\hline
\end{tabular}

The interviews showed that in particular farmers and stakeholders in regions with light, sandy soils are interested in the technique and think it has potential to be effective. Interviewees describe sandy subsoils as a rather unattractive environment for plant roots, as water drains quickly and washes out plant nutrients. In this context, they see the technique as a way to improve the site conditions: Injecting organic material into the subsoil would increase the organic matter content and thereby enhance its ability to store water and nutrients, while at the same time attracting soil organisms and enhancing biological activity in the soil. One farmer illustrated this as follows:

"Roots usually do not want to grow into the subsoil here, due to its physical properties: often it is compacted, it cannot hold water nor nutrients, in the worst case it is toxic and has the wrong $\mathrm{pH}$ value. In this case they don't want to grow down there and of course [the technique] has an effect, because substrate is incorporated and the roots like to grow in there. It is like a flower-pot-effect: the substrate holds water and nutrients-things that the other subsoil cannot provide. Hence there has to be a yield benefit" (No. 18).

Similarly, one farm advisor stated:

"We have a lot of sandy soils, sandy loams, and all organic material that we incorporate into the soil is generally positive. You increase the organic matter, the humus content; enhance biological activity, microorganism, etc. I see positive effects. Particularly for sandy soils I see benefits" (No. 2). 
By delivering these benefits, the technique is also seen by some to have the potential to stabilise yields. As mentioned above, yield stabilisation is a strong motivation for farmers, particularly in areas with high annual yield variations such as Mecklenburg-Western Pomerania, Brandenburg, and Saxony-Anhalt. For example, one farmer in Brandenburg reported that he was able to harvest nine tons of wheat per hectare in one year, and only 4.5 tons per ha in the following year. To some farmers, reducing such fluctuations and preventing very low yields in years with droughts is more important than increasing yields on a percentage basis. Finally, as an additional positive effect, interviewees mentioned that the incorporation of organic matter could improve the soil structure and thus prevent re-compaction.

On the other hand, both those that are open to the technique and those who were sceptical found the technique to be associated with a high effort and high costs. One farmer even said that the technique was not feasible even if the effects were positive and sustained. A key open question is whether the expected benefits are worth the high effort, particularly in comparison with the common practices of incorporating compost into the topsoil or in comparison with applying catch crops, which also have the benefit of improving soil structure and reducing the risk of compaction.

Due to the expected high costs of the technique, it is perceived to be attractive only for crops with a high added value, such as in horticulture (for example, for berry production). At the same time, the higher costs mean that it is likely not to be accessible for smaller farms, and as such, also in line with the technical/digitalisation development associated with structural change in agriculture. One farmer likened the high cost of the approach to the investments required for putting in place drainage in organic soils. This farmer, who is quite open to technical innovations, also mentioned that the high work intensity associated with the procedure could be negated if a subcontractor performed the task. For other farmers, this reliance on external subcontractors is seen as a hindrance to the technique. This implies that farmers who value their independence are less likely to be interested in the injection of organic matter: "This technique makes farmers dependent on experts that come from the outside and tell him how he should improve his soils" (No. 4).

Mostly, stakeholders cited the risk of a negative impact on soil structure as a key disadvantage of the technique, questioning whether the assumed positive effect on the subsoil will offset the disruption made to the topsoil. One questioned the sensibility of mechanically penetrating soil at such depths, when the same can be achieved with biological methods. This is particularly a concern when the technique is applied under suboptimal conditions. Moreover, several interviewees voiced the concern about anaerobic decomposition and the risk of rotting, especially in heavy soils with low air circulation. This would also mean that the nutrients brought into the subsoil are not available to plants. One farmer argued that this risk was lower on sandy soils. One stakeholder argued that this measure should be combined with improving soil biology, particularly in conventionally cultivated fields that typically have little soil life, so that there are sufficient soil organisms to convert the input materials.

Several stakeholders stressed the need for rigorous testing and scientific monitoring of the technique, and doubted whether the technique would allow all soil functions to be maintained. Another open question about maintaining the yield increase-one farmer questioned whether the yield effect is primarily associated with the loosening in the first year which brings in oxygen, but that this effect cannot last. The source of organic material was a source of concern for some, i.e., that compost and other organic materials might be polluted with plastic residues or heavy metals; and that the quality of compost is essential. Moreover, there was concern that the technique would cause compaction on the edges of the furrows.

Soil stakeholders with an environmental background raised the concern about interference with natural and archive soil functions, for example, and that this technique would need to be carefully restricted. In particular, ecological effects are difficult to judge since the processes, functions, and organisms in subsoil are not yet well known. The criticism expressed by these environmental stakeholders also focused around the perception that advocates of the technique (including researchers) focus too much on the expected positive impacts for the production and yields, whereas the (potential) 
negative ecological side-effects are overlooked-for example, the negative impact on the buffering and filtering function of the subsoil (No. 9). Potentially, a key limitation to the technique is linked to the risk of groundwater pollution and the breach of compliance with the Fertiliser Ordinance, i.e., whether plants effectively take up nitrogen that has been injected in deep soil layers, or whether this will leach to groundwater as nitrate (No. 2). This risk is perceived to be higher than in the case of fertilizer input in the topsoil, and the stakeholder thought this would be the primary objection by environmental societal actors.

\subsubsection{Alfalfa Cultivation}

In contrast to the more diverse views on mechanical subsoiling and the injection of organic matter in furrows, both farmers and stakeholders recognised alfalfa cultivation as a positive method for soil management in general and more specifically to ameliorate the subsoil. The large majority of them, however, also stressed the economic disadvantages of cultivating this crop (compare Table 6).

Table 6. Stakeholders' views on Alfalfa.

\begin{tabular}{cc}
\hline Positive & Negative \\
\hline $\begin{array}{c}\text { Improved structure, biological activity, } \\
\text { infiltration capacity } \\
(1,2,4,5,7,8,9,14,16)\end{array}$ & $\begin{array}{c}\text { Economically not attractive to most farmers due to } \\
\text { limitations on usage of the crop and opportunity costs } \\
(1,2,4,5,6,7,8,10,11,12,13,14,15,16,17)\end{array}$ \\
\hline $\begin{array}{c}\text { Effective remediation option for compacted soils, } \\
\text { suitable for most soil types } \\
(1,3,5,6,7,8,9,10,13,16,18)\end{array}$ \\
Wealth of experience \\
$(3,7,10)$ \\
\hline $\begin{array}{c}\text { Good component in the crop rotation, increased yield } \\
\text { in the following years when applied for two years } \\
\text { or more }\end{array}$ \\
$\begin{array}{c}(1,3,4,8,9,10,12,14,17,18) \\
\text { Effective method to reduce compaction without the } \\
\text { risk of recompaction } \\
(5,7,9)\end{array}$ \\
\hline
\end{tabular}

The positive impression of alfalfa is in large part based on a pool of positive experience with this technique in Germany. Biological subsoil loosening by means of alfalfa is a widely known concept among farmers and stakeholders, who were all aware of the deep rooting potential of the alfalfa plant. Moreover, they either had their own experience with alfalfa cultivation or had heard about its successful application elsewhere and thus regard its effectiveness to remediate compacted soils as proven. The following stakeholders' quotes illustrate these points:

"Alfalfa is an excellent component in the crop rotation in order to loosen the soil. In particular, when it is on the field longer than one year-usually three years maximum—the soil you have afterwards, it is a dream" (No. 1).

"When comparing to our normal crops, no other crop has such root power" (No. 17).

"After having had alfalfa a couple of years on a field, you will have a much better harvest of wheat on this field in the three following years than on your other fields, by far. [ . . ] If I had an organic farm or a dairy farm, I would definitely cultivate alfalfa" (No. 12).

"We intensely cultivated alfalfa. We have generated our best soils by first ameliorating them through perennial alfalfa cultivation and breaking up numerous compacted soil horizons this way. By this, we accessed many nutrients from the subsoil. [ ... ] But this is nothing 
new. My great grandparents already knew what alfalfa and other deep-rooting crops can do. This is 200-year-old knowledge" (No. 10).

Alfalfa is perceived as a suitable crop for most soil types in Germany. Soil stakeholders estimate that the positive effect of alfalfa on soils and related yield increases of the subsequent crop last about three years or longer. More importantly, what makes alfalfa cultivation an attractive subsoil management technique in the eyes of many stakeholders is that it generates multiple benefits on soils while providing an option to remediate compacted soils. In addition to breaking up compacted soil layers, stakeholders mentioned that it enhances and stabilises the soil structure, increases pore volume and biological activity, activates the self-regulation of the soil, and contributes to an overall recovery of the soil ecosystem.

The multiple positive impacts of alfalfa cultivation on soil functions were particularly important to environmental stakeholders who highlighted the multifunctionality of soils. These stakeholders often expressed a clear preference for biological subsoil management over mechanical approaches (five of the six stakeholders with a multifunctional view of subsoils). In their view, a major advantage of alfalfa cultivation lies in the fact that it does not pose any risks to soils (such as re-compaction or destruction of soil structure), that the effects last longer, and that it is a holistic approach enhancing the entire soil. For example, one respondent explained:

"I think this is by far the best way to improve the subsoil, because you have a lot of positive side effects on the soil, which in the end are reflected in the yields. This means you don't only achieve what you aimed for, but at the same time improve the entire soil structure in the upper horizons and create hotspots of soil bacteria" (No. 4).

However, all farmers and stakeholders except for one believe that this technique is currently not economically attractive for the majority of farms in Germany. One central issue is the usage of the crop: in order to cultivate alfalfa, farmers need to be able to use or sell the alfalfa harvest. Cultivating alfalfa only for improving the soil is seen as very unlikely. The main use of alfalfa is as a fodder crop for cattle. One farmer stated that "Alfalfa is the 'queen of fodder plants'. The complete US-American market for milk production is based on alfalfa and corn. Why don't we do this here in Germany?" (No. 10). A farm advisor argued that feeding alfalfa is increasingly attractive for dairy farms, as nowadays, many dairies demand that fodder is GMO-free, which soy often is not (No. 1).

On farms without cattle, alfalfa can be sold either to neighbour farms or to dry pellet producers. Several farmers reported that in Brandenburg, Bavaria, and Baden-Wuerttemberg, alfalfa cultivation is interesting as a business option within a certain radius of drying units that operate there. Overall, however, the potential for alfalfa seems to be rather limited: for farmers who do not raise cattle, have no neighbouring dairy or cattle farmers, and have no dry fodder unit in the region, alfalfa is at present not an economically attractive option.

In addition to the potential usage for the crop, another economic disadvantage of alfalfa is that the plant has to stay on the field for two or three years to be able to develop its deep rooting system and have its desired effect for soils. The opportunity cost of this cultivation can be significant, for example, in comparison with winter wheat or sugar beets. While many believe this is acceptable for organic farms, this trade-off is a limiting factor for the uptake among conventional farmers-even if there are utilization options for the alfalfa produce. The following statements illustrate this:

"If you cultivate alfalfa systematically over several years, you probably have a very positive effect without risking negative side-effects of technical interventions. But you need time and patience" (No. 9).

"[Alfalfa cultivation is] economically not attractive for farmers, because the investment does not return within a short period of two or maximally four years" (No. 7).

"Having alfalfa or a similar plant for soil recovery in the crop rotation is usually an economic advantage when calculating profit margins over five years" (No. 4). 
The dominant way of calculating costs and gains over a short time-period hinders the uptake of such biological approaches to improving the soil. The longer time needed for seeing positive benefits means that alfalfa cultivation is especially a barrier for uptake on land that is leased, since farmers are less willing to invest in such a technique if they do not have the guarantee of benefitting. Especially stakeholders with a multifunctional understanding of soil criticised the focus on cash crops in Germany and the related neglect of biological approaches, such as alfalfa cultivation, as a means to improve the condition of soils. It was suggested that this barrier could be overcome by better informing farmers about the benefits of alfalfa cultivation, and by calculating the cost and benefits over a longer time.

It is worth noting that other deep rooting crops may have a similar positive effect on subsoil. Stakeholders and farmers often mentioned oil radish, lupine, and buckwheat. In addition, one farmer mentioned broad beans that develop roots of about $1.5 \mathrm{~m}$, have a similar effect on the soil as alfalfa, and yet are suitable as feed for pigs. Another farmer recommended red clover, which can be undersown.

One farmer and part-time farm advisor found that the example of alfalfa and other deep rooting crops is reflective of the environmental limitations of farming based on cash crops with limited crop rotation. On the one hand, such production leads to an increased risk of compaction due to the use of heavy machinery, and on the other hand, does not allow the soil any 'room to breathe' nor to benefit from its natural resilience to maintain soil structure (No. 17). The immediate short-term opportunity costs associated with integrating deep-rooting cover crops or cereals in crop rotation also mean that these crops may not be planted after applying mechanical subsoiling, even though they would have the benefit of stabilising the soil structure.

\section{Discussion}

Our research has shown that, although subsoil has not been a visible part of the policy agenda and is not visible to the eye, farmers and other stakeholders included in this study show a clear awareness of its importance for agricultural production. A distinction, however, can be made between a more productivist and a more multifunctional view of subsoil. These views differ in the extent to which the non-productive functions and services are explicitly important. In this sense, the distinction is more narrow than usually made in literature (see, for example [19,30,31]). It is an important consideration since societal acceptance of management methods includes at least two aspects: the 'private' benefit that farmers accrue from implementing the method, mostly focused on yield, and the wider public benefits. The stakeholders that hold a more multifunctional view of subsoil also considered the wider public benefits or risks of subsoil management to a greater degree. If the production function is a key lens through which the subsoil is perceived, the impact on other soil functions appears not to be as important.

This resonates with literature that has shown that individual problem framings and perceptions towards soil degradation influence the interpretation, attitude, and actions that follow and how a soil is managed [21-23]. Our research indicates that how a person perceives the subsoil in terms of its functions is linked to the view they hold on the acceptance of management options. If subsoil functions other than the productive/yield function are not part of farmers' view of the subsoil, the awareness of risks to those functions also appears to be absent. Awareness and knowledge of soil risks, however, can be a motivating factor to adopt sustainable soil measures (see [24]).

The study also shows that the relative importance of subsoil for agricultural production varies depending on the quality of the topsoil, as well as climatic conditions. Nonetheless, the awareness of subsoil as a reservoir of nutrients and water $[8,9,12]$ is present not only among farmers with poor topsoil (light, sandy soils with frequent drought conditions), but also by those with better topsoil. This shows that biophysical conditions and farming system characteristics can have a significant influence on the acceptance of different management methods at a farm level and the 'ability' to adopt a measure. Because biophysical conditions also influence the impact of individual methods on soil structure and functions, these are also limiting factors for practical feasibility and acceptance of methods from a broader societal perspective. 
Of the subsoil management methods for which we sought to gain an understanding of farmers' and stakeholders' perceptions, there is quite high agreement among both groups on two methods. First, negative opinions towards deep ploughing dominate due to its perceived harmful impacts on soil structure and soil functions, as well as the high energy requirements needed to implement the technique. This finding is in contrast to the conclusion of Schneider et al. (2017) [12], that deep ploughing can be a suitable technique to increase yields on certain soil types when combined with measures to build up soil organic matter in the new topsoil. Our findings suggest that stakeholders and farmers see deep ploughing as an outdated and problematic method, and at present, it is also unlikely to be implemented in Germany. Only three of 18 interviewees saw the method acceptable as a one-time method for very specific conditions.

Second, farmers and other stakeholders perceive alfalfa cultivation (as well as other deep rooting crops) as a beneficial soil management method with a positive impact on soil structure and soil functions, including the production function and yields. The method is seen as both a prevention and a remediation method and resonates with the stakeholders' and farmers' understanding of good soil management. In line with this, abundant scientific evidence points to the multiple benefits of biological approaches, although not referring to them as subsoil management. Studies show that diversifying crops and crop rotations can enhance soil organic matter, biodiversity, and the provision of ecosystem services [32-34], as well increase the resilience of cropping systems and better adapt them to climate change [35-37]. Schneider et al. (2017) state that, in terms of yields, deep-rooting crops are preferable to mechanical deep tillage options for certain soil types [12].

However, interviewees see the uptake of alfalfa cultivation and other perennial, deep-rooting crops limited by economic constraints (potential usage and opportunity costs) and the prevalent focus on simplified crop rotations, including a focus on cash crops. Similarly, Reckling et al. (2016) [38] show that the cultivation of forage legumes such as alfalfa, despite their various environmental benefits, is restricted to farms which have utilization options. They identify the focus on short-term income as a barrier for the integration of legumes into crop rotations in Europe: "Farmers and advisors seldom consider the long-term benefits, focusing instead on single years. This leads to an underestimation of the services provided by legumes" [38] (p. 12). One question emerging from this analysis is, therefore, how can these barriers be overcome in order to enhance the integration of alfalfa and other deep-rooting crops for the purpose of subsoil management? An increase in the cultivation of alfalfa would be in line with a recent policy initiative to increase crop diversification and improve crop rotations (in particular, via the Common Agricultural Policy), as well as with the German Protein Crop Strategy (see [39]).

Stakeholders and farmers expressed mixed feelings on mechanical subsoil loosening (subsoiling). While some thought it important to have a means to quickly break up severely compacted soil layers, others criticized the technique to be a mere technical short-term fix that does not solve the problem. A further concern expressed by various interviewees is that mechanical subsoiling can severely damage soils when applied under unfavourable conditions (such as wet subsoil). The risk of a negative impact on soil structure and the risk of re-compaction with detrimental consequences is a significant limitation to mechanical subsoiling, both for practice and from the perspective of delivering public benefits. A number of scientific studies mirror this view and argue that the prevention of subsoil compaction is preferable to subsoiling $[3,40,41]$.

In contrast to the cultivation of alfalfa or other deep-rooting crops, stakeholders and farmers in the sample do not see mechanical subsoiling as part of good soil management, as the technique per se does not contribute to the prevention of compaction or soil health in general. Yet, it was also stated that mechanical subsoiling could be accepted when applied as a one-time measure that goes hand in hand with adequate changes in the farming system, such as diversifying the crop rotation, using deep-rooting intercrops, and preventing frequent traffic on the field. Researchers in Sweden who tested inter-row subsoiling on potato fields came to a similar conclusion, depicting subsoiling as "a short-term solution that needs to be repeated time after time, unless it is combined with good cultivation practices and perhaps other methods to alleviate soil compaction" [42] (p. 25). While it 
is not possible to say exactly how widely subsoiling is practiced (according to a representative of the German Agricultural Soil Inventory, this is limited to approximately 5\% of agricultural land in Germany), this study suggests that there is a need for an increased awareness of subsoiling risks, preventing compaction, and re-compaction among practitioners, as well as policy-makers.

For injecting organic material furrow-wise into the subsoil, views are diverse, ranging from enthusiasm over scepticism to opposition. On the one hand, farmers and stakeholders see the potential for the method to improve access to water and nutrients, enhance site conditions and soil structure, and stabilise yields, especially in dry regions with sandy soils. On the other hand, and not surprisingly given the early stages of research on this technique, many open questions remain about the likely effects and thus its societal acceptance. It appears clear though that even if the questions on the effects are resolved in a positive way, the technique is only likely to be an acceptable solution for very specific conditions.

Our analysis suggests that injecting organic material furrow-wise into the subsoil is likely to be an attractive option for North-Eastern Germany with its light, sandy soils and its pronounced drought risk, where subsoil compaction is a common phenomenon. Under these conditions, the technique is perceived to have the potential to contribute to stabilizing yields and delivering a good cost-benefit outcome. Moreover, one could argue that a number of further enhancing factors come together in this region. It seems that from the perspective of farmers, the concern related to impairing soil quality is lower when soil on the farm is poor compared to farms with high soil quality. In addition, it requires less physical strength to work deep soil layers of sandy soils compared to heavier soil types. A further enhancing factor might be that farms in North-Eastern Germany are on average larger compared to Southern Germany, and hiring agricultural contractors for certain field work is more common.

However, while a first valuation of a field experiment of this technique after one year [10] only focused on yield effects, we found that a range of other effects on soil functions and ecosystem service provision are relevant for the acceptance of this technique. These include, in particular, impacts on the buffering and filtering function on the subsoil. Interviews also pointed to the fact that the design of the technique as a furrow-wise application might enhance its acceptance. In contrast to a treatment of the complete field, a furrow-wise application on the one hand saves costs for labour and fuel-which is an important factor for farmers [43] — and on the other hand, it presents a less intensive intervention into the soil with overall less pressure on soil structure and soil biota.

\section{Conclusions}

In this study, we have identified a range of views on subsoil management methods. While the small sample size and exploratory nature of the study mean that we cannot draw conclusions with certainty, the analysis points to a number of key acceptance factors for the different subsoil management techniques. Biophysical conditions and the timing of operations are of significant importance for the impact and acceptance of mechanical intervention methods. Overall, views on mechanical interventions are more diverse and, in some cases, more critical, because the benefits are not always certain, the costs can outweigh the benefits, and/or because they entail risk for soil structure and functions. Awareness of multiple subsoil functions is associated with more critical views of mechanical interventions. The cultivation of alfalfa (and other deep rooting crops) is seen to be beneficial for yields without risks for soil structure and functions; however, economic barriers limit its uptake. The study underlines that yields and impacts on other soil functions, as well as the site-specificity of impacts and economic barriers, need to be taken into account in discussions on the role of subsoil management as an option to sustainably maintain yields in the context of climate change and resource scarcity.

Although farmers and stakeholders currently rarely consider the subsoil in their soil management decisions, we expect that, due to an increasing drought risk and resource scarcity issues, as well as continuing subsoil compaction, the importance of subsoil management will increase in Germany. 
The issue requires more attention in policy discussions on soil protection and food security in light of changing climate conditions and ongoing soil degradation.

Future work will examine the acceptance of subsoil management in a broader representative sample for Germany and engage with stakeholders in a participatory process to provide inputs to scientific research on the impacts and design of two methods: the alfalfa cultivation and the injection of organic matter furrow-wise into the subsoil.

Author Contributions: A.F.-L. and M.H. designed the concept for the study and the interview guidelines, conducted the analysis, and wrote the paper. S.I. substantially contributed to the analysis and the writing of the paper.

Funding: This article was prepared as part of the BonaRes research project "Sustainable Subsoil Management as Part of the Bioeconomy" (Soil ${ }^{3}$ ) funded by the German Federal Ministry of Education and Research (BMBF), grant number 031B0026F.

Acknowledgments: We would like to thank our interview partners for sharing their views, knowledge, and experiences in the field of subsoil management. We thank Zoritza Kiresiewa and Evelyn Lukat for their great help in data gathering and the background literature search.

Conflicts of Interest: The authors declare no conflict of interest. The founding sponsors had no role in the design of the study; in the collection, analyses, or interpretation of data; in the writing of the manuscript, and in the decision to publish the results.

\section{References}

1. Frelih-Larsen, A.; Bowyer, C.; Albrecht, S.; Keenleyside, C.; Kemper, M.; Nanni, S.; Naumann, S.; Mottershead, R.D.; Landgrebe, R.; Andersen, E.P.; et al. Updated Inventory and Assessment of Soil Protection Policy Instruments in EU Member States; Ecologic Institute: Berlin, Germany, 2018.

2. Paleari, S. Is the European Union protecting soil? A critical analysis of Community environmental policy and law. Land Use Policy 2017, 64, 163-173. [CrossRef]

3. Schjønning, P.; van den Akker, J.J.H.; Keller, T.; Greve, M.H.; Lamandé, M.; Simojoki, A.; Stettler, M.; Arvidsson, J.; Breuning-Madsen, H. Chapter Five-Driver-Pressure-State-Impact-Response (DPSIR) Analysis and Risk Assessment for Soil Compaction-A European Perspective. In Advances in Agronomy; Academic Press: New York, NY, USA, 2015; pp. 183-237.

4. Jones, A.; Panagos, P.; Erhard, M.; Tóth, G.; Barcelo, S.; Bouraoui, F.; Bosco, C.; Dewitte, O.; Gardi, C.; Hervás, J.; et al. The State of Soil in Europe: A Contribution of the JRC to the European Environment Agency's Environment State and Outlook Report-SOER 2010; JRC \& European Environment Agency: Luxembourg, 2012.

5. ten Berge, H.F.M.; Schröder, J.J.; Olesen, J.E.; Giraldez Cervera, J.-V. Research for AGRI Committee—Preserving Agricultural Soils in the EU; European Parliament, Policy Department for Structural and Cohesion Policies: Brussels, Belgium, 2017.

6. Schoumans, O.F.; Bouraoui, F.; Kabbe, C.; Oenema, O.; van Dijk, K.C. Phosphorus management in Europe in a changing world. AMBIO 2015, 44, 180-192. [CrossRef] [PubMed]

7. Leinweber, P.; Bathmann, U.; Buczko, U.; Douhaire, C.; Eichler-Löbermann, B.; Frossard, E.; Ekardt, F.; Jarvie, H.; Krämer, I.; Kabbe, C.; et al. Handling the phosphorus paradox in agriculture and natural ecosystems: Scarcity, necessity, and burden of P. AMBIO 2018, 47, 3-19. [CrossRef] [PubMed]

8. Kautz, T.; Amelung, W.; Ewert, F.; Gaiser, T.; Horn, R.; Jahn, R.; Javaux, M.; Kemna, A.; Kuzyakov, Y.; Munch, J.-C.; et al. Nutrient acquisition from arable subsoils in temperate climates: A review. Soil Biol. Biochem. 2012, 57, 1003-1022. [CrossRef]

9. Gaiser, T.; Perkons, U.; Küpper, P.M.; Puschmann, D.U.; Peth, S.; Kautz, T.; Pfeifer, J.; Ewert, F.; Horn, R.; Köpke, $U$. Evidence of improved water uptake from subsoil by spring wheat following lucerne in a temperate humid climate. Field Crop. Res. 2012, 126, 56-62. [CrossRef]

10. Jakobs, I.; Schmittmann, O.; Schulze Lammers, P. Short-term effects of in-row subsoiling and simultaneous admixing of organic material on growth of spring barley (H. vulgare). Soil Use Manag. 2017, 33, 620-630. [CrossRef]

11. Köpke, U.; Athmann, M.; Han, E.; Kautz, T. Optimising Cropping Techniques for Nutrient and Environmental Management in Organic Agriculture. Sustain. Agric. Res. 2015, 4, 15. [CrossRef] 
12. Schneider, F.; Don, A.; Hennings, I.; Schmittmann, O.J.; Seidelc, S. The effect of deep tillage on crop yield-What do we really know? Soil Tillage Res. 2017, 174, 193-204. [CrossRef]

13. Lynch, J.P.; Wojciechowski, T. Opportunities and challenges in the subsoil: Pathways to deeper rooted crops. J. Exp. Bot. 2015, 66, 2199-2210. [CrossRef] [PubMed]

14. Ottoy, S.; Van Meerbeek, K.; Sindayihebura, A.; Hermy, M.; Van Orshoven, J. Assessing top- and subsoil organic carbon stocks of Low-Input High-Diversity systems using soil and vegetation characteristics. Sci. Total Environ. 2017, 589, 153-164. [CrossRef] [PubMed]

15. Salomé, C.; Nunan, N.; Pouteau, V.; Lerch, T.Z.; Chenu, C. Carbon dynamics in topsoil and in subsoil may be controlled by different regulatory mechanisms: CARBON DYNAMICS IN TOPSOIL AND IN SUBSOIL. Glob. Chang. Biol. 2010, 16, 416-426. [CrossRef]

16. Ball, B.C.; Batey, T.; Munkholm, L.J.; Guimarães, R.M.L.; Boizard, H.; McKenzie, D.C.; Peigné, J.; Tormena, C.A.; Hargreaves, P. The numeric visual evaluation of subsoil structure (SubVESS) under agricultural production. Soil Tillage Res. 2015, 148, 85-96. [CrossRef]

17. Kautz, T.; Athmann, M.; Köpke, U. Growth of barley (Hordeum vulgare L.) roots in biopores with differing carbon and nitrogen contents. In Building Organic Bridges; Rahmann, G., Aksoy, U., Eds.; Johann Heinrich von Thünen-Institut: Braunschweig, Germany, 2014; Volume 2, pp. 391-394.

18. Alcántara, V.; Don, A.; Well, R.; Nieder, R. Deep ploughing increases agricultural soil organic matter stocks. Glob. Chang. Biol. 2016, 22. [CrossRef] [PubMed]

19. Wilson, G.A.; Burton, R.J.F. 'Neo-productivist' agriculture: Spatio-temporal versus structuralist perspectives. J. Rural Stud. 2015, 38, 52-64. [CrossRef]

20. Mills, J.; Gaskell, P.; Ingram, J.; Dwyer, J.; Reed, M.; Short, C. Engaging farmers in environmental management through a better understanding of behaviour. Agric. Hum. Values 2016. [CrossRef]

21. Prager, K.; Curfs, M. Using mental models to understand soil management. Soil Use Manag. 2016, 32, 36-44. [CrossRef]

22. Ingram, J.; Mills, J.; Dibari, C.; Ferrise, R.; Ghaley, B.B.; Hansen, J.G.; Iglesias, A.; Karaczun, Z.; McVittie, A.; Merante, P.; et al. Communicating soil carbon science to farmers: Incorporating credibility, salience and legitimacy. J. Rural Stud. 2016, 48, 115-128. [CrossRef]

23. Ingram, J.; Fry, P.; Mathieu, A. Revealing different understandings of soil held by scientists and farmers in the context of soil protection and management. Land Use Policy 2010, 27, 51-60. [CrossRef]

24. Boardman, J.; Bateman, S.; Seymour, S. Understanding the influence of farmer motivations on changes to soil erosion risk on sites of former serious erosion in the South Downs National Park, UK. Land Use Policy 2017, 60, 298-312. [CrossRef]

25. Ingram, J. Technical and Social Dimensions of Farmer Learning: An Analysis of the Emergence of Reduced Tillage Systems in England. J. Sustain. Agric. 2010, 34, 183-201. [CrossRef]

26. Cai, H.; Ma, W.; Zhang, X.; Ping, J.; Yan, X.; Liu, J.; Yuan, J.; Wang, L.; Ren, J. Effect of subsoil tillage depth on nutrient accumulation, root distribution, and grain yield in spring maize. Crop J. 2014, 2, 297-307. [CrossRef]

27. Leskiw, L.A.; Welsh, C.M.; Zeleke, T.B. Effect of subsoiling and injection of pelletized organic matter on soil quality and productivity. Can. J. Soil Sci. 2012, 92, 269-276. [CrossRef]

28. Cresswell, H.; Kirkegaard, J. Subsoil amelioration by plant-roots-The process and the evidence. Aust. J. Soil Res. 1995, 33, 221-239. [CrossRef]

29. Gill, J.S.; Sale, P.W.G.; Tang, C. Amelioration of dense sodic subsoil using organic amendments increases wheat yield more than using gypsum in a high rainfall zone of southern Australia. Field Crop. Res. 2008, 107, 265-275. [CrossRef]

30. Wilson, G.A. From 'weak' to 'strong' multifunctionality: Conceptualising farm-level multifunctional transitional pathways. J. Rural Stud. 2008, 24, 367-383. [CrossRef]

31. Wilson, G.A. From productivism to post-productivism ... and back again? Exploring the (un)changed natural and mental landscapes of European agriculture. Trans. Inst. Br. Geogr. 2001, 26, 77-102. [CrossRef]

32. Tiemann, L.K.; Grandy, A.S.; Atkinson, E.E.; Marin-Spiotta, E.; McDaniel, M.D. Crop rotational diversity enhances belowground communities and functions in an agroecosystem. Ecol. Lett. 2015, 18, 761-771. [CrossRef] [PubMed]

33. Garratt, M.P.D.; Bommarco, R.; Kleijn, D.; Martin, E.; Mortimer, S.R.; Redlich, S.; Senapathi, D.; Steffan-Dewenter, I.; Świtek, S.; Takács, V.; et al. Enhancing Soil Organic Matter as a Route to the Ecological Intensification of European Arable Systems. Ecosystems 2018, 1-12. [CrossRef] 
34. Monteleone, M.; Cammerino, A.R.B.; Libutti, A. Agricultural "greening" and cropland diversification trends: Potential contribution of agroenergy crops in Capitanata (South Italy). Land Use Policy 2018, 70, 591-600. [CrossRef]

35. Lin, B.B. Resilience in Agriculture through Crop Diversification: Adaptive Management for Environmental Change. BioScience 2011, 61, 183-193. [CrossRef]

36. Gaudin, A.C.M.; Tolhurst, T.N.; Ker, A.P.; Janovicek, K.; Tortora, C.; Martin, R.C.; Deen, W. Increasing Crop Diversity Mitigates Weather Variations and Improves Yield Stability. PLoS ONE 2015, 10, e0113261. [CrossRef] [PubMed]

37. Isbell, F.; Adler, P.R.; Eisenhauer, N.; Fornara, D.; Kimmel, K.; Kremen, C.; Letourneau, D.K.; Liebman, M.; Polley, H.W.; Quijas, S.; et al. Benefits of increasing plant diversity in sustainable agroecosystems. J. Ecol. 2017, 105, 871-879. [CrossRef]

38. Reckling, M.; Bergkvist, G.; Watson, C.A.; Stoddard, F.L.; Zander, P.M.; Walker, R.L.; Pristeri, A.; Toncea, I.; Bachinger, J. Trade-Offs between Economic and Environmental Impacts of Introducing Legumes into Cropping Systems. Front. Plant Sci. 2016, 7, 669. [CrossRef] [PubMed]

39. Bundesministerium für Ernährung und Landwirtschaft. Ackerbohne, Erbse \& Co. Die Eiweißpflanzenstrategie des Bundesministeriums für Ernährung und Landwirtschaft zur Förderung des Leguminosenanbaus in Deutschland; Bundesministerium für Ernährung und Landwirtschaft: Bonn, Germany, 2016.

40. Chamen, T.W.C.; Moxey, A.P.; Towers, W.; Balana, B.; Hallett, P.D. Mitigating arable soil compaction: A review and analysis of available cost and benefit data. Soil Tillage Res. 2015, 146, 10-25. [CrossRef]

41. Schjønning, P.; Lamandé, M.; Crétin, V.; Aalborg Nielsen, J. Upper subsoil pore characteristics and functions as affected by field traffic and freeze-thaw and dry-wet treatments. Soil Res. 2016, 55, 234-244. [CrossRef]

42. Ekelöf, J.; Guamán, V.; Jensen, E.S.; Persson, P. Inter-Row Subsoiling and Irrigation Increase Starch Potato Yield, Phosphorus Use Efficiency and Quality Parameters. Potato Res. 2015, 58, 15-27. [CrossRef]

43. Techen, A.-K.; Helming, K. Pressures on soil functions from soil management in Germany. A foresight review. Agron. Sustain. Dev. 2017, 37, 64. [CrossRef]

(C) 2018 by the authors. Licensee MDPI, Basel, Switzerland. This article is an open access article distributed under the terms and conditions of the Creative Commons Attribution (CC BY) license (http:/ / creativecommons.org/licenses/by/4.0/). 